\title{
Short communication: \\ Environment and morphometric of sea hare Dolabella auricularia from shrimp pond, Sorong, West Papua, Indonesia
}

\author{
ACHMAD SOFIAN ${ }^{1}$, ACHMAD SUHERMANTO ${ }^{1, \bullet}$, SAIDIN ${ }^{1}$, MOHAMMAD SAYUTI ${ }^{1}$, DIAN NOVIANTO ${ }^{2}$, \\ FERLIANA WIDYASARI ${ }^{3}$ \\ ${ }^{1}$ Politeknik Kelautan dan Perikanan Sorong. Jl. K. Pattimura, Tanjung Kasuari, Sorong City 98411, West Papua, Indonesia. Tel./fax.: +62-951-3100182, \\ •email: ac.suhermanto.apsor@gmail.com \\ ${ }^{2}$ Pangandaran Integrated Aquarium and Marine Research Institute (Piamari Pangandaran). Babakan, Pangandaran 46396, West Java, Indonesia \\ ${ }^{3}$ Coastal and Marine Resource Management Center of Sorong. Jl. KPR PDAM No. Km 10, Klawuyuk, Sorong City 98416, West Papua, Indonesia
}

Manuscript received: 28 October 2020. Revision accepted: 24 January 2021.

\begin{abstract}
Sofian A, Suhermanto A, Saidin, Sayuti M, Novianto D, Widyasari F. 2021. Short communication: Environment and morphometric of sea hare Dolabella auricularia from shrimp pond, Sorong West Papua, Indonesia. Biodiversitas 22: 983-987. Dolabella auricularia is a herbivorous marine biota living on the shallow seabed, which is found mostly in Indo-Pacific waters. The purpose of this study was to analyze the environmental and morphometric characteristics of Dolabella auricularia which live in vaname shrimp pond, Sorong, West Papua, Indonesia. Samples were collected from April to June 2020. From the measurement of pond waters environmental conditions, the following data were obtained: temperatures ranging from $31.47 \pm 1.08^{\circ} \mathrm{C}$, salinity ranging from $31.91 \pm$ $2.29 \mathrm{ppt}$, pH ranging from $8.02 \pm 0.20$, brightness $108.00 \pm 45.63 \mathrm{~cm}$, and Dissolved Oxygen (DO) ranging from $4.10 \pm 0.22 \mathrm{mg} / \mathrm{L}$. The morphometrics of D. auricularia consisted of R-Anterior resp distances with sizes ranging from $38.9 \pm 17 \mathrm{~mm}$, wet weight ranging from $170 \pm 34 \mathrm{~g}$ total lengths ranging from $112 \pm 57.83 \mathrm{~mm}$, posterior diameters ranging from $71 \pm 41 \mathrm{~mm}$. D. auricularia was found in pond waters as a pest for shrimp culture. However, D. auricularia also has biomedical and economic potentials as raw materials for the pharmaceutical industry. So, further studies are needed for their development.
\end{abstract}

Keywords: Dolabella auricularia, environment, morphometric, sea hare, shrimp pond

\section{INTRODUCTION}

Indonesia is an archipelagic country with a coastline of $95181 \mathrm{~km}$ and two-thirds of its territory being oceans located in the Indo-Pacific region (Maulidia et al. 2019). Because of its geographical condition, Indonesia is rich in biodiversity. Indonesia as one of the countries in Southeast Asia with high biodiversity or megadiverse countries has many variations and is very abundant, known as mega biodiversity (Chasanah 2008; Sukara 2008; Keong 2015; Rintelen et al. 2017). Indonesia has a strategic location in the Indo-Pacific region, which is on the biodiversity path of the Asian continent (Sumatra, Java, Kalimantan) and Australia (Papua) as well as in the Wallace transitional zone (Sulawesi, Maluku and Nusa Tenggara; Chasanah 2008). Biogeographic, geological, climatic, and ecological factors result in a high diversity of endemic fauna and species (Lohman et al. 2011). Marine biodiversity is a potential natural resource that can be developed for improving community welfare.

Marine invertebrates such as sea hare are known to have self-defense capabilities by producing chemical defenses. However, their physical movement structures are more limited than marine vertebrates (Murniasih 2005). Dolabella auricularia is a mollusk species found on tidal plains and is consumed as food in the Philippines (Pepito et al. 2015; Ramos et al. 2018; Tsuji 2019). Sea hare is a herbivorous animal usually found in shallow water and feeds on algae and seagrass (Singh and Vuki 2015). The habitat of the sea hare is shallow marine waters with sand on the bottom. It can also be found in shrimp farms, such as Bursatella leachii (Opisthobranchia: Aplysiidae) found in Thai shrimp ponds (Arkronrat et al. 2016); however, the presence of other species such as $D$. auricularia in shrimp ponds have not been reported.

Sea hare species of $D$. auricularia can be found in the Indo-Pacific region (Gosliner et al. 1996; Manullang et al. 2016). D. auricularia is a marine invertebrate commonly found on the seabed with sandy bottom and corals or on seaweed (Toruntju et al. 2020); it consumes a wide variety of seagrass (Singh and Vuki 2015) and has a potential to be developed as a natural ingredient in the pharmaceutical field (Toruntju et al. 2020). In Indonesia, D. auricularia is found in Konawe waters, Southeast Sulawesi (Manullang et al. 2016; Toruntju et al. 2020). D. auricularia is also found in shrimp pond in Sorong. Dolabela auricularia can adapt to the pond environment, while its natural habitat is in the sea with a sandy bottom. Dolabela auricularia is also known to have economic value as a medical raw material (Kamiya et al. 2006; Cheung et al. 2015). So, it is necessary to observe environmental and morphometric characteristics. The exploration study of D. auricularia in ponds is expected to provide useful information for increasing the value of biota, conservation, and 
development. This study aims to analyze the environment and morphometrics of $D$. auricularia in shrimp ponds in Sorong, West Papua.

\section{MATERIALS AND METHODS}

\section{Samples and study area}

Samples of Dolabella auricularia were obtained from vaname shrimp pond in Sorong, West Papua, Indonesia. The location of the pond is very close to the coastal waters of Tanjung Kasuari, Sorong City $\left(0^{\circ} 49^{\prime} 46^{\prime \prime} \mathrm{S}, 131^{\circ} 14^{\prime} 3^{\prime \prime} \mathrm{E}\right)$. There were 2 units of HDPE plastic ponds with an area of about $1700 \mathrm{~m}^{2}$ each. The pond functions as a reservoir and a medium for cultivating vaname shrimp. The analysis was carried out on the characteristics of the pond water environment and the morphometrics of $D$. auricularia. The identification of environmental characteristics was carried out in the ponds and around the coastal waters of Tanjung Kasuari, Sorong City which were done from April to June 2020. A sample of 30 individuals was measured in terms of wet weight and morphometrics, including measurements of total length, diameter, and weight by referring to Sethi et al. (2014) and Manullang et al. (2016). The equipment used consists of the Global Positioning System (GPS), camera, caliper, scale, dissecting set, and AM200 Aquaread water quality.

\section{RESULTS AND DISCUSSION}

\section{The environmental condition of shrimp farms}

The shrimp ponds are located close to the coastal waters of Tanjung Kasuari, Sorong City. Geographically, the waters of Sorong are located at the bird's head of Papua Island, which is directly connected to the Pacific Ocean in the north, which is part of the Indo-Pacific. This allows rich marine life to spread to the island of Papua. Indo-Pacific waters are also the distribution area of $D$. auricularia (Gosliner et al. 1996; Manullang et al. 2016). The coastal waters of Tanjung Kasuari Sorong (Figure 1) are also a source of water (inlet) for shrimp ponds in Sorong, allowing biota seeds from marine waters such as $D$. auricularia to be carried by the flow through the pipe.

The shrimp pond has a total area of about $3,400 \mathrm{~m}^{2}$ and a plastic pond area of $\pm 1700 \mathrm{~m}^{2}$. The pond is covered with HDPE plastic with an embankment height of $3 \mathrm{~m}$, and a slope towards the outlet door of about $2^{\circ}$. The water source is obtained from the coast using a $200 \mathrm{~m}$ PVC pipe with a diameter of 6 inches with a depth of 1.5-2.5 $\mathrm{m}$ in the sea. Water from the sea is collected in a reservoir. It is then put into the maintenance pond through a pipe that has been equipped with a layered waring as a water filter. The water depth in the ponds is between $1.50-1.60 \mathrm{~m}$. The biota that is cultivated is vaname shrimp (Litopenaeus vannamei), with an average stocking density of $59 \mathrm{pcs} \mathrm{m}^{-2}$.

Dolabella auricularia was found in shrimp aquaculture ponds from the $20^{\text {th }}$ to the $40^{\text {th }}$ day of the cycle, attached to the walls of the plastic ponds in the morning until sunrise and in the evening when the sun begins to set. In higher temperature conditions, this biota tool shelter in the pond bottom. Young D. auricularia was taken to overcome the presence of this mollusk in shrimp ponds, which is considered a pest. The manual collection used a filter net obtained about 80-100 per day. The density of $D$. auricularia began to decrease after the maintenance of vaname shrimp over the $40^{\text {th }}$ day of rearing until harvest, presumably due to reduced feed availability.

The development of $D$. auricularia follows the development cycle of shrimp culture in ponds. Its existence is influenced by the water quality of the shrimp rearing media and feed as an energy source. The water from the sea flows through the inlet to the reservoir and then into the shrimp pond. About three weeks after the beginning of the shrimp culture cycle, $D$. auricularia seeds can be seen at the edge of the pond and occasionally also on lift nets for sampling. The results of the measurement of water quality parameters during the maintenance period are shown in Table 1

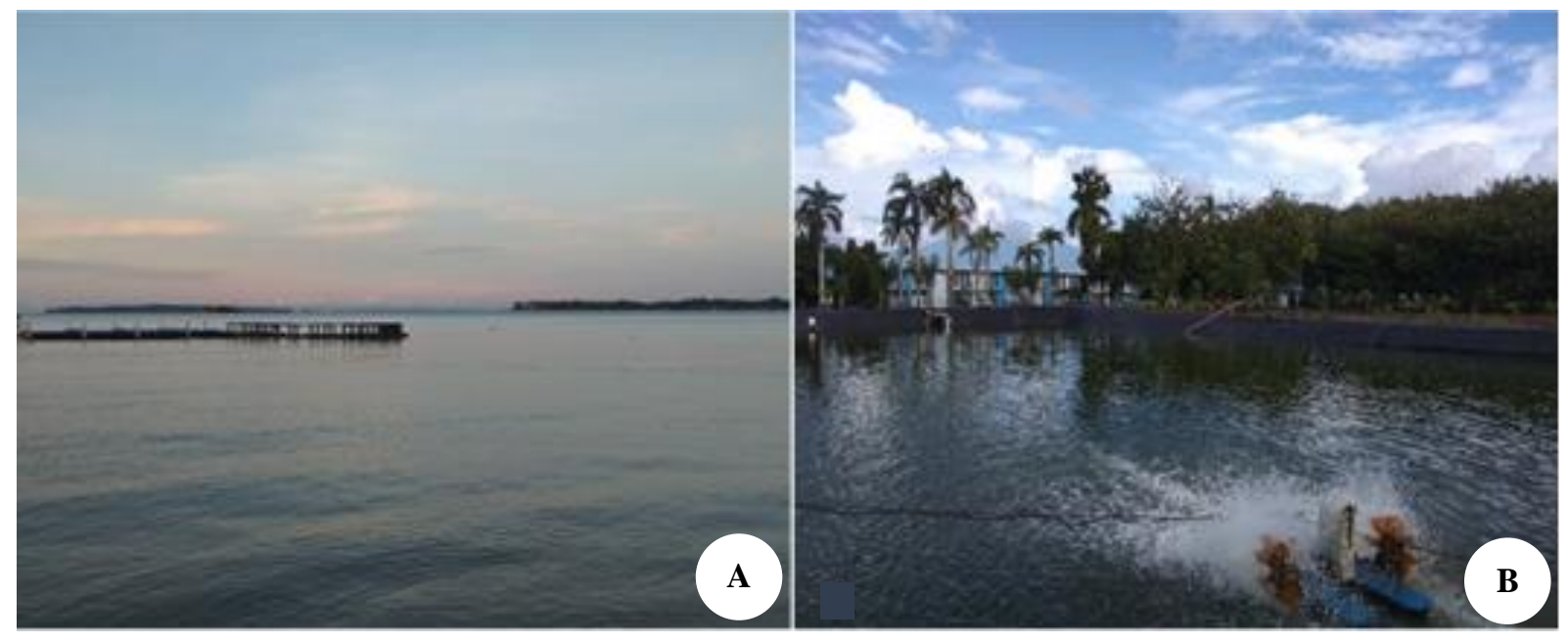

Figure 1. Waters of Tanjung Kasuari, Sorong Beach, West Papua, Indonesia (A) and shrimp farms (B) 
Table 1. The results of the measurement of water quality parameters

\begin{tabular}{ccccc}
\hline Temperature $\left({ }^{\circ} \mathbf{C}\right)$ & Salinity $(\mathbf{p p t})$ & $\mathbf{p H}$ & Brightness $(\mathbf{c m})$ & Dissolved oxygen $(\mathbf{m g} / \mathbf{L})$ \\
\hline $31.47 \pm 1.08$ & $31.91 \pm 2.29$ & $8.02 \pm 0.20$ & $108.00 \pm 45.63$ & $4.10 \pm 0.22$ \\
\hline
\end{tabular}

\section{Sea hare characteristics}

Sea hares commonly live in shallow waters where algae can be found (Manullang et al. 2016). The observed sea hare belongs to the gastropod group, the family of Aplysiidae, and the genus of Dolabella, with species name of Dolabella auricularia (Lightfoot 1786).

Dolabella auricularia has several characteristics, including living in waters with warm temperatures; having purple ink which serves as protection from attacks by predators; consuming green and brown algae such as Sargassum sp.; nocturnal; actively consuming algae at night; having green and brown colors according to its natural food sources; and as a decoration in the aquarium (Gosliner et al. 2015; Manullang et al. 2016; Nimbs et al. 2017; Priscilla et al. 2019).

Based on the observations, D. auricularia shrimp pond in Sorong has the following characteristics, began to emerge to the surface by sticking to the walls of the plastic pond in the morning and evening and sometimes at night, it was detected that it appeared on the pond surface since the 20th day of the vaname shrimp culture cycle. Morphologically, it looks like a snail. Life cycle following the growth of vaname shrimp in the pond, possibly entering the pond during water filling, the larvae then utilized the plankton to grow and develop. When harvesting the shrimp, after 90 days of the shrimp rearing period, 30-50 $D$. auricularia were found with different size variations. $D$. auricularia found in ponds is green, brown and black. However, the population of the black one is about $10-15 \%$ of the total caught when rearing shrimp. When harvesting shrimp, only $D$. auricularia was found, which was greenish and brownish in color. When removed, D. auricularia will experience stress and discharge clear mucus and dark purple ink. D. auricularia occurs only at night and may exhibit nocturnal characteristics (Gosliner et al. 2015). Spawning occurs throughout the year, with two peaks: one May to July, the other September to October in the Philippines (Pauly and Calumpong 1984). Spawn masses present in July and August in Zanzibar (Bebbington 1974). The larvae are obligate planktotrophic and may allow the larvae to travel large distances on ocean currents (Kempf 1981). D. auricularia with brown color was found in India (Sethi et al. 2014). This animal is an aplysiid with colors olive green (Pettit and $\mathrm{Xu} 2001$ ), depending on diet and habitat (Nimbs et al. 2017).

The results of morphological observations of $D$. auricularia showed that it has a pair of tentacles on the anterior and a shell covering the ink glands on the posterior side. The top (A) and bottom (B) cross-sectional images, as well as the dorsal shell from the anterior respiratory opening (C) are presented in Figure 2.

Dolabella auricularia has body parts, from the head to the posterior, and the morphology shown in Figure 3. According to Bebbington (1974), the body parts of $D$. auricularia consist of cephalic tentacle, eye, rhinophores, external autospermal groove, inhalant siphon (anterior respiratory opening), parapodia, posterior disc and exhalant siphon (posterior respiratory opening).

Dolabella auricularia was also found in the form of tillers at the age of 30-35 days of vaname shrimp rearing in the pond (Figure 4). The morphometric observations were carried out on 30 samples of $D$. auricularia including total length (dorsal-ventral), posterior diameter, and wet weight as presented in Table 2.

The aquaculture environment of the shrimp pond in Sorong has dynamic characteristics. It is close to the coast and has inlet and outlet channels connected to marine waters. D. auricularia commonly live in the bottom of shallow marine waters. The existence of sea hare in shrimp ponds showed that this biota develops in the aquatic environment of shrimp ponds. D. auricularia also has biomedical and economic potentials as raw materials in the pharmaceutical sector because it has bioactive content that is used for anti-cancer, antitumor peptide/macrolides, antioxidant, and antibacterial (Kamiya et al. 2006; Cheung et al. 2015; Tayone et al. 2020; Tayone 2020). The bioactive compounds, specially aplyronines and dolastatins, isolated from the sea hares belonging mainly to two species: Aplysia kurodai and Dolabella auricularia (Yamada et al. 2010). According to Manullang et al. (2016), not much information on the nutritional content of D. auricularia is available, so it has not been widely used. However, the impact of the presence of sea hare on shrimp culture still needs to be studied further (Arkronrat et al. 2016).

Table 2. Morphometric of Dolabella auricularia

\begin{tabular}{lccc}
\hline \multicolumn{1}{c}{ Parameters } & Max. & Min. & Average \pm SD \\
\hline R-Anterior resp. distances $(\mathrm{mm})$ & 38.90 & 17 & $25.53 \pm 5.75$ \\
Wet weight $(\mathrm{g})$ & 170 & 34 & $76.10 \pm 36.04$ \\
Total length $(\mathrm{mm})$ & 112 & 57.83 & $74.68 \pm 13.99$ \\
Posterior diameter $(\mathrm{mm})$ & 71 & 41 & $52.42 \pm 6.89$ \\
\hline
\end{tabular}




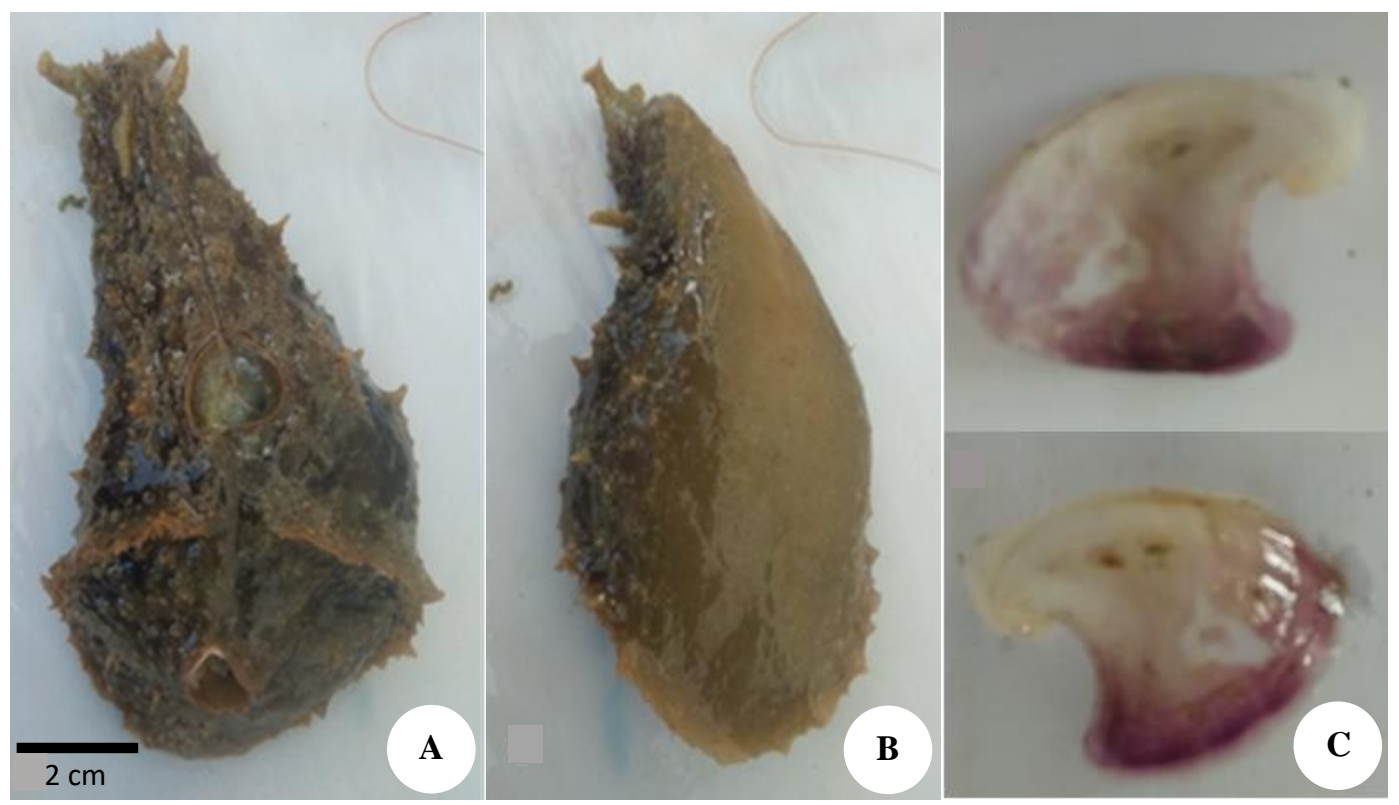

Figure 2. Dolabella auricularia top view (A), and bottom view (B). Shell dorsal from anterior respiratory opening (C)
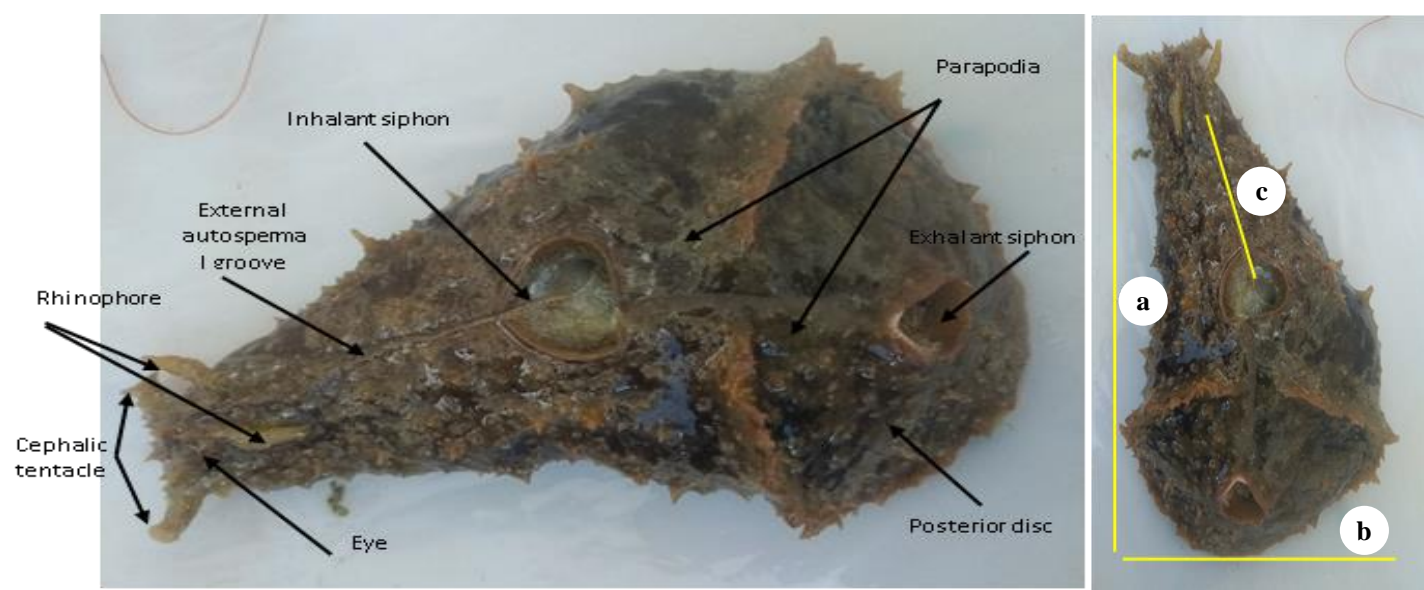

Figure 3. A. Body parts of Dolabella auricularia. B. Morphology of D. auricularia: a. Total length; b. Posterior diameter; c. R-Anterior respiratory distance

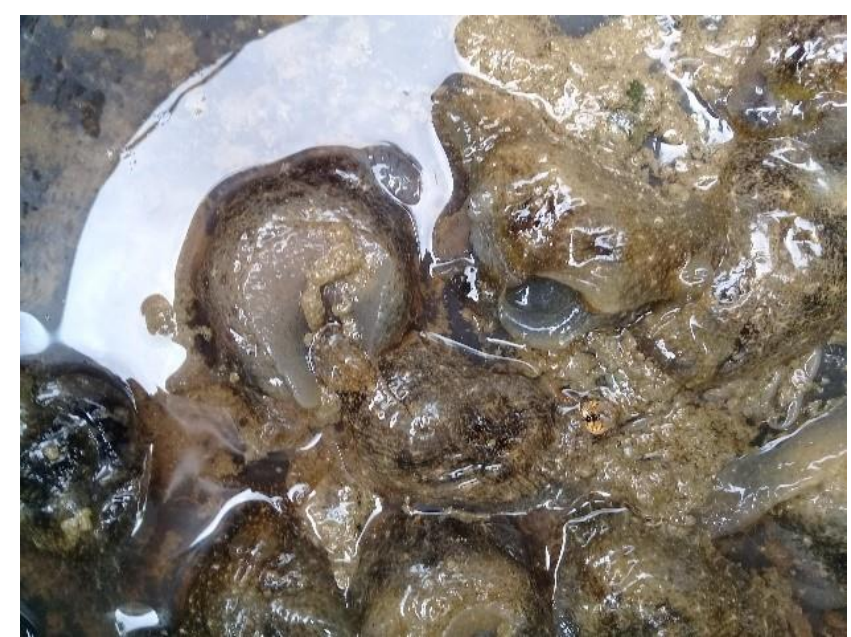

Figure 4. Young Dolabella auricularia aged 30-35 days of vaname shrimp pond
This study showed that sea hare is a species that is likely to be tolerant of environmental dynamics such as pond waters. Chávez-Viteri and Ward (2017) described that sea hare is tolerant of high pressure from environmental stressors, such as $\mathrm{pH}$ and temperature. The type of food eaten by D.auricularia and its habitat greatly affects the color of this mollusk (Nimbs et al. 2017). It is assumed that the pond waters contain plankton as a feed for sea hare and affect its body color. D. auricularia samples were obtained from green and brown dominant shrimp ponds. Therefore, cultivation is possible because of the high economic potential to use sea hare as a pharmaceutical material based on the secondary metabolites it produces. It may sea hare being symbiosis with vaname shrimp. Based on the farmers' information, the increase of sea hare, correlated with the productivity of vaname shrimp. Further studies may focus on the distribution of $D$. auricularia species, shrimp pond culture, and the presence of $D$. auricularia. Its 
secondary metabolite content and economic potential can provide more comprehensive information on this species.

In conclusion, D. auricularia is commonly found in shrimp farms from day 20 to day 40 during the rearing cycle. D. auricularia is tolerant of the shrimp pond in Sorong environment and was found to variant size. $D$. auricularia is found in the aquatic environment of shrimp ponds, but it is still considered a pest. However, $D$. auricularia also has biomedical and economic potentials as raw materials for the pharmaceutical industry and other potentials. Therefore, further studies are needed for their development.

\section{ACKNOWLEDGEMENTS}

The authors are very grateful to the shrimp pond unit, Politeknik Kelautan dan Perikanan Sorong, Indonesia. The authors declare no conflict of interest.

\section{REFERENCES}

Arkronrat W, Printrakoon C, Oniam V. 2016. Occurrence of ragged sea hare (Bursatella leachii) in marine shrimp ponds, Prachuap Khiri Khan Province, Thailand. Proceedings of $54^{\text {th }}$ Kasetsart University Annual Conference: Plants, Animals, Veterinary Medicine, Fisheries, Agricultural Extension and Home Economics. Bangkok, 2-5 February 2016. [Thailand].

Bebbington A. 1974. Aplysiid species from East Africa with notes on the Indian ocean Aplysiomorpha (Gastropoda: Opisthobranchia). Zool J Linn Soc 54 (1): 63-99. DOI: 10.1111/j.1096-3642.1974.tb00793.x

Chasanah E. 2008. Marine biodiscovery research in Indonesia: Challenges and rewards. J Coast Dev 12 (1): 1-12.

Chávez-Viteri YE, Ward S. 2017. Effects of Ocean Acidification and Warming on the Embryogenesis and Larval Behaviour of the Sea Hares Aplysia dactylomela and Dolabella auricularia (Opisthobranchia: Anaspidea). [Thesis]. University of Queensland, Australia. [Australia]

Cheung RCF, Ng TB, Wong JH. 2015. Marine peptides: Bioactivities and applications. Mar Drugs 13 (7): 4006-4043. DOI: 10.3390/md13074006.

Gosliner T, Behrens DW, Williams GC. 1996. Coral Reef Animals of the Indo-Pacific: Animal Life from Africa to Hawaii Exclusive of the Vertebrates. A Sea Challengers publication, University of California, CA.

Gosliner TM, Behrens DW, Valdés A. 2015. Nudibranch \& Sea Slug Identification: Indo-Pacific. New World Publications, Jacksonville, FL.

Kempf SC. 1981. Long-lived larvae of the gastropod Aplysia juliana: Do they disperse and metamorphose or just slowly fade away. Mar Ecol Prog Ser 6: 61-65.

Keong CY. 2015. Sustainable resource management and ecological conservation of mega-biodiversity: The Southeast Asian Big-3 reality. Intl J Environ Sci Dev 6 (11): 876-882. DOI: 10.7763/IJESD.2015.V6.715.

Lohman D, Bruyn Md T, Rintelen Kv, Hall R, Ng PL, Shih H, Carvalho $\mathrm{G}$, von Rintelen T. 2011. Biogeography of the Indo-Australian
Archipelago. Ann Rev Ecol Evolut Syst 42 (1): 205-226. DOI: 10.1146/annurev-ecolsys-102710-145001.

Manullang B, Purwaningsih S, Azrifitria A. 2016. Karakteristik asam amino, asam lemak dan mineral kelinci laut. Jurnal Pengolahan Hasil $\begin{array}{llll}\text { Perikanan Indonesia } 19 & \text { (2): 168-176. DOI: }\end{array}$ 10.17844/jphpi.2016.19.2.168.

Maulidia M, Dargusch P, Ashworth P, Ardiansyah F. 2019. Rethinking renewable energy targets and electricity sector reform in Indonesia: A private sector perspective. Renew Sustain Energ Rev 101: 231-247. DOI: 10.1016/j.rser.2018.11.005.

Murniasih T. 2005. Substansi kimia untuk pertahanan diri dari hewan laut tak bertulang belakang. Oseana 30 (2): 19-27. [Indonesian].

Nimbs MJ, Willan RC, Smith SD. 2017. Is Port Stephens, Eastern Australia, a global hotspot for biodiversity of Aplysiidae (Gastropoda: Heterobranchia)? Molluscan Res 37 (1): 45-65. DOI: 10.1080/13235818.2016.1207280.

Pauly D, Calumpong H. 1984. Growth, reproduction and mortality of the sea hare Dolabella auricularia (Gastropoda: Aplysiidae) in the Central Visayas, Philippines. Mar Biol 79 (3): 289-293.

Pepito AR, Delan GG, Abdon HC, Lamayo MH, Aballe RS, Lamayo RC. 2015. Post-harvest treatments and heavy metal content in the egg mass of wedge sea hare Dolabella auricularia (Lightfoot, 1786). Trop Technol J 18 (1): 1-6.

Pettit GR, Xu JP. 2001. U.S. Patent No. 6,239,104. Patent and Trademark Office, Washington DC, U.S.

Priscilla V, Sedayu A, Patria MP. 2019. Microplastic abundance in the water, seagrass, and sea hare Dolabella auricularia in Pramuka Island, Seribu Islands, Jakarta Bay, Indonesia. J Physics: Conf Ser 1402: 033073. DOI: 10.1088/1742-6596/1402/3/033073.

Ramos DA, Batomalaque GA, Anticamara JA. 2018. Current status of Philippine mollusk museum collections and research, and their implications on biodiversity science and conservation. Philipp J Sci 147 (1): 123-163

Von Rintelen K, Arida E, Häuser C. 2017. A review of biodiversityrelated issues and challenges in megadiverse Indonesia and other Southeast Asian countries. Res Ideas Outcomes 3: e20860. DOI: 10.3897/rio.3.e20860

Kamiya H, Sakai R, Jimbo M. 2006. Molluscs: Bioactive molecules from sea hares. In: Cimino G, Gavagnin M (eds). The Chemo-Ecological Study to Biotechnology Application. Springer, Berlin-Heidelberg.

Sethi SN, Ranhith L, Kannan K. 2014. Occurrences of wedge sea hare, Dolabella auricularia (Lightfoot, 1786) from Kayalpatinam, Gulf of Mannar, Tamil Nadu, India. Indian J Geo-Mar Sci 43 (8): 1546-1549.

Singh SK, Vuki VC. 2015. An ecological study of the sea hare, Dolabella auricularia, on the southeastern coast of Viti Levu, Fiji. SPC Women in Fisheries Information Bulletin, 26 December 2015.

Sukara E, Tobing SL. 2008. Industri berbasis keanekaragaman hayati masa depan Indonesia. Jurnal Vis Vitalis 1 (2): 1-12. [Indonesian].

Tayone JC, Ortiz JC, Tayone WC. 2020. Selected mollusks from Pujada Bay, Philippines: Heavy metal health risk assessment and antibacterial activities. Asian J Biol Life Sci 9 (2): 177.

Tayone JC. 2020. Investigation of chemical composition and antibacterial activity of ink from Sea hare Dolabella auricularia. Walailak J Sci Technol 17 (6): 600-607. DOI: 10.48048/wjst.2020.3075.

Tsuji T. 2019. An ethnography on the wedge sea hare in Mactan island, the Philippines. Naditira Widya 13 (2): 135-150. [Indonesian]

Toruntju SA, Banudi L, Leksono P, Rahmat M, Salma WO. 2020. Identification of secondary metabolite contents on marine rabbit extract (Dolabella auricularia). IOP Conf Ser: Earth Environ Sci 465: 012038. DOI: 10.1088/1755-1315/465/1/012038.

Yamada K, Ojika M, Kigoshi H, Suenaga K. 2010. Cytotoxic substances from two species of Japanese sea hares: Chemistry and bioactivity. Proc Japan Acad Ser B Phys Biol Sci 86 (3): 176-189. 